\title{
Parental allele specific methylation of the human insulin-like growth factor II gene and Beckwith-Wiedemann syndrome
}

Hélène Schneid, Danielle Seurin, Marie-Paule Vazquez, Micheline Gourmelen, Sylvie Cabrol, Yves Le Bouc

\begin{abstract}
In an attempt to elucidate the role of methylation in parental imprinting at the IGF-II gene locus, for which imprinting has already been described in the mouse; we undertook an allele specific methylation study of the human IGF-II gene (mapped to $11 \mathrm{p} 15.5$ ) in a control population and in patients with Beckwith-Wiedemann syndrome.

In control leucocyte DNA (16 unrelated adults and eight families), the maternal allele of the IGF-II gene was specifically hypomethylated, whereas no such allele specific methylation was found for either the insulin or the calcitonin genes which are located in $11 \mathrm{p} 15.5$ and $11 \mathrm{p} 15.1$, respectively. Furthermore, the IGF-II gene specific hypomethylation was localised on the 5 ' portion of exon 9.

In the patients with Beckwith-Wiedemann syndrome in which the IGF-II gene is thought to be involved and where paternal isodisomy has been described, hypomethylation of the maternal allele was conserved in leucocyte DNA, but abnormal methylation was detected in malformed tissues where the paternal allele was also demethylated. Some specific mechanism linked to methylation therefore seems to be involved in the pathogenesis of Beckwith-Wiedemann syndrome.

( M Med Genet 1993;30:353-62)
\end{abstract}

Various family studies have indicated that there is a link between Beckwith-Wiedemann syndrome and the $11 \mathrm{p} 15$ region of chromosome $11^{12}$ which also carries the insulin-like growth factor II (IGF-II) gene. ${ }^{3}$ This syndrome causes childhood malformation and is characterised by a number of congenital disorders (neonatal gigantism, omphalocele, macroglossia, visceromegaly, hemihypertrophy, and neonatal hypoglycaemia) and is frequently associated with tumours (nephroblastoma, adrenocortical carcinoma, neuroblastoma, and hepatoblastoma). ${ }^{45}$ Expression of IGF mRNA has been seen to increase in a variety of tumours $^{6-15}$ and IGF-II is known to play a pivotal role in cell proliferation ${ }^{16}$ and embryonic development. ${ }^{17}$ In addition, DeChiara et al ${ }^{18}$ have recently used homologous recombination to show that the murine IGF-II gene is subject to differential parental imprinting. The mechanisms involved in the regulation of this imprinting remain largely unknown, but some observations indicate a relationship between parental imprinting and methylation of the alleles. ${ }^{18-20}$

We have therefore analysed the genomes of a control population and of children with Beckwith-Wiedemann syndrome and their families in order to determine whether DNA methylation might be linked to differential parental imprinting of the human IGF-II gene.

\section{Patients}

Twenty-seven unrelated subjects and the brothers (P3C2 and P16C2) of two patients (P3C1 and $\mathrm{P} 16 \mathrm{C} 1$ ) were analysed (15 boys and 14 girls). Their clinical findings are listed in table 1 which shows the major anomalies associated with Beckwith-Wiedemann syndrome. In 16 cases (patients P1 to P15, including the sibs $\mathrm{P} 3 \mathrm{C} 1$ and $\mathrm{P} 3 \mathrm{C} 2$ ) the symptoms were those of a complete form of Beckwith-Wiedemann syndrome. For the patient $\mathrm{P} 3 \mathrm{C} 2$, a fetal serum sample was obtained for a variety of echographic abnormalities and for karyotype analysis. Four patients (P16 to P19) had a smaller number of anomalies and were diagnosed as having an incomplete form of the syndrome. Patient P16C1 had a brother, P16C2, who had a neuroblastoma, but no symptoms of Beckwith-Wiedemann syndrome. Four other patients (P20 to P23) were not diagnosed as having the syndrome, but nevertheless presented isolated major clinical symptoms typical of it and were therefore classified as cases with isolated signs of the Beckwith-Wiedemann syndrome. Two patients exhibited macroglossia (P20 and P21), one hemihypertrophy (P22), and one an omphalocele (P23). Among the 25 patients with signs of Beckwith-Wiedemann syndrome, seven developed tumours: P1, a neuroblastoma and a nephroblastoma; $\mathrm{P} 2$, a nephroblastoma; $\mathrm{P} 3 \mathrm{C} 1$, a ganglioneuroma; P3C2, bilateral nephroblastoma; P6, a nephroblastoma; $\mathrm{P} 16 \mathrm{Cl}$, an adrenocortical carcinoma; and $\mathrm{P} 16 \mathrm{C} 2$, a neuroblastoma. In addition to the above, four children were 


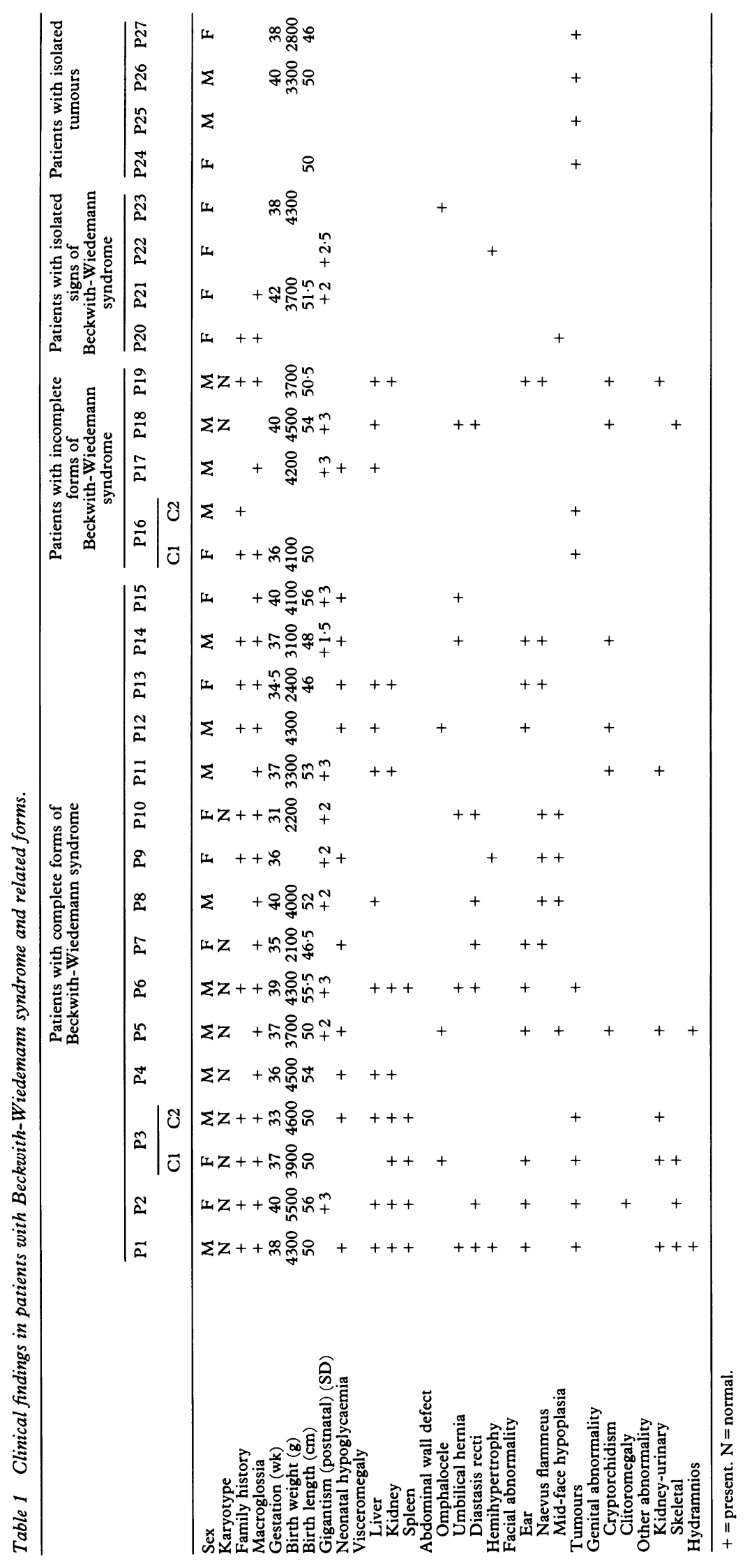


investigated with no signs of Beckwith-Wiedemann syndrome, but with embryonic tumours often associated with the syndrome, such as adrenocortical carcinoma (P24), neuroblastoma (patients P25 and P26), and nephroblastoma (P27).

Family analysis was possible in 14 cases, both parents of P1, P3, P5, P6, P7, P9, P10, P13, P14, P16, P19, P20, and only the mothers of patients P2 and P24.

\section{Controls}

The control population has been described previously ${ }^{15}$ : 16 unrelated subjects and eight families (including 10 children and 16 parents) were studied.

\section{Materials and methods \\ SAMPLES}

Blood samples from controls and patients were collected in anticoagulant (EDTA) and stored at $-80^{\circ} \mathrm{C}$ until use for DNA extraction. Tissues, either from tumours $(\mathbf{P} 1, \mathbf{P} 24)$ or from partial glossectomy (P1, P6 to P10, P13, P14, P20), were removed from surgical patients, frozen immediately in liquid nitrogen, and stored at $-80^{\circ} \mathrm{C}$ until use.

\section{ISOLATION OF DNA AND RNA FROM BLOOD AND TISSUES}

Leucocyte DNA was isolated as previously described. $^{21}$ Total DNA and RNA were extracted simultaneously from frozen tissue (for the nine samples mentioned above except for P13 for which only DNA analysis was available) according to Chirgwin et $a l^{22}$ with some modifications as previously described. ${ }^{15}$ Spectrometry at 260 and $280 \mathrm{~nm}$ was used for DNA and RNA quantification. Nucleic acid integrity was routinely checked by ethidium bromide staining.

\section{PROBES}

The human placental IGF-II cDNA insert P35 (vector $\lambda$ gt 10$)^{23}$ was subcloned in plasmid PGEM4 (pTG 3907). The 663 bp EcoRI fragment containing $15 \mathrm{bp}$ of the $5^{\prime}$ untranslated region (exon 6 ), the coding region, and $99 \mathrm{bp}$ of the $3^{\prime}$ untranslated region (exons $7,8,9$ ) of

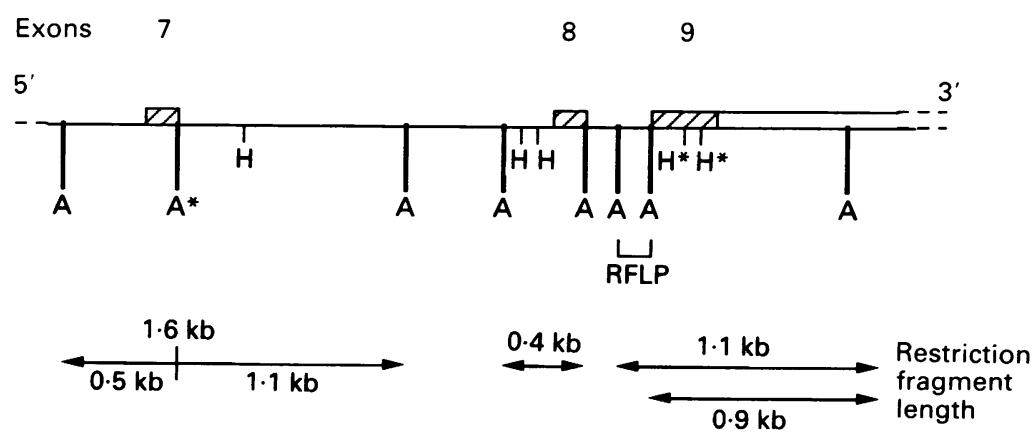

Figure 1 Map of the relationship between AvaII and HpaII sites on the IGF-II gene around exons 7,8 , and 9; hatched areas correspond to the cDNA probe used. $A=$ AvalI site: $C C A($ or $T) G G . A^{*}=$ specific Avall site, methylation sensitive, depending on tissue of origin. ${ }^{15} H=H$ palI site: $C C G G$. $H^{*}=$ specific HpaII site, sensitive to parental allele specific methylation. The fragments detected by Southern blotting after AvalI digestion are shown at the bottom. the IGF-II cDNA was used as probe. Numbering of exons was based on the nomenclature for the IGF genes as published. ${ }^{24}$ An exon 7 specific probe (a $159 \mathrm{bp}$ fragment) was obtained by EcoRI/AvaII digestion, and an exon 9 probe (a $356 \mathrm{bp}$ fragment) by SalI/ $E c o$ RI digestion of the $663 \mathrm{bp} \mathrm{cDNA}$ insert.

The human insulin $2.7 \mathrm{~kb} \mathrm{BglII-XhoI} \mathrm{frag-}$ ment was kindly provided by $\mathrm{P}$ Holthuizen ${ }^{25}$ and the $827 \mathrm{bp}$ human calcitonin cDNA probe by A Julienne. ${ }^{26}$

DNA probes were labelled with $\alpha^{32} \mathrm{P}$-dATP by random priming (kit, Amersham, England) to a specific activity of $2 \times 10^{9} \mathrm{cpm} / \mu \mathrm{g} \mathrm{DNA}$, as indicated by the manufacturer.

\section{SOUTHERN BLOT ANALYSIS}

Ten micrograms of DNA were digested with 120 units of restriction endonuclease, according to the manufacturer's specifications (Appligene, France or New England Biolabs Inc, USA). DNA fragments were separated by electrophoresis on $0.7 \%$ to $1.2 \%$ agarose gels, then denatured and transferred to a nylon membrane (Gene Screen Plus, New England Nuclear, USA) using the alkaline method. Finally they were hybridised to ${ }^{32} \mathrm{P}$-labelled probes as previously described. ${ }^{21}$

Enzymes were selected for Southern blot analysis on the basis of the polymorphic patterns yielded: $A v a$ II and SacI for the IGF-II gene, ${ }^{15}$ SacI and TaqI for the insulin gene, ${ }^{27}$ and TaqI for the calcitonin gene. ${ }^{28}$

Double digests were used to study allele methylation (fig 1). The initial enzyme was used to detect polymorphism and to distinguish the alleles from each other. The second digestion was done with a methylation sensitive enzyme, HpaII, through which methylation of the CCGG site could be determined by comparison with the fragments obtained with its methylation insensitive isoschizomer Msp I.

A specific profile was detected with AvaII for the IGF-II gene in some tissues where DNA was demethylated and the $1.6 \mathrm{~kb}$ fragment was cleaved to a $0.5 \mathrm{~kb}$ fragment, as previously described ${ }^{15}$ (fig 1 ).

DOT BLOT AND NORTHERN BLOT ANALYSIS

For dot blot analysis, RNA samples were dotted onto a Hybond- $\mathrm{N}$ membrane (Amersham, England) using a Hybri-dot (BRL, USA) apparatus as previously described. ${ }^{15}$ For Northern blot analysis, denatured total RNA was loaded onto $1 \cdot 2 \%$ agarose-formaldehyde gels for electrophoresis, then transferred to Hybond-N membranes (Amersham, England), as previously reported. ${ }^{15}$

The blots were hybridised according to the manufacturer's instructions with $3 \times 10^{6} \mathrm{cpm} /$ $\mathrm{ml}$ of ${ }^{32} \mathrm{P}$ labelled probe, then washed twice at room temperature and once at $65^{\circ} \mathrm{C}$, each for 20 minutes, in $0.1 \times$ SSPE $(1 \times$ SSPE $=0.01 \mathrm{~mol} / 1 \quad \mathrm{NaH}_{2} \mathrm{PO}_{4}, \mathrm{pH} 6.8,0.001 \mathrm{~mol} / 1$ EDTA- $\mathrm{Na}_{2}, 0.15 \mathrm{~mol} / 1 \mathrm{NaCl}$ ) and $0.1 \% \mathrm{SDS}$, before being exposed to $x$ ray film (Curix RP1- 
Agfa) at $-80^{\circ} \mathrm{C}$ with intensifying screens (Dupont Cronex Hiplus).

\section{Results}

ALLELE SPECIFIC METHYLATION OF THE IGF-II GENE IN CONTROL LEUCOCYTES

In order to determine whether DNA methylation is linked to differential imprinting of the IGF-II gene, Southern blot analyses were done, using a system of double digestion to identify the methylation state of each of the alleles of the IGF-II gene, as described above. Sixteen unrelated adults were investigated, all of whom were heterozygous with AvaII for the IGF-II gene. As can be seen from a comparison of the $A v a \mathrm{II}$ digest and the $A v a \mathrm{II} /$ $M s p$ I double digest shown in fig 2, all AvaII fragments $(1.6,1.1 / 0.9,0.4 \mathrm{~kb})$ were cleaved by $M s p \mathrm{I}$, indicating that all contained some CCGG sequence. The AvaII/HpaII double digest, by contrast, showed a conserved AvaII profile, but with major differences in the polymorphic $1 \cdot 1 / 0.9 \mathrm{~kb}$ fragments. Both alleles were capable of cleavage by HpaII, but in all 16 samples examined, only one allele was cleaved, whether it was the $1 \cdot 1 \mathrm{~kb}$ (nine samples, $56 \%$ ) or the $0.9 \mathrm{~kb}$ allele (seven samples,
$44 \%$ ). This indicates specific hypomethylation of only one allele.

The same analyses were done in eight informative families (10 children and 16 parents), and in all cases it was the maternal allele that was hypomethylated. Two examples are shown in fig 3.

In order to localise the AvaII fragments detected by Southern blotting, hybridisation experiments were done with IGF-II exon 7 and exon 9 specific probes. As shown in fig 4, the $1.6 \mathrm{~kb}$ AvaII fragment was specifically detected by the exon 7 probe, whereas the polymorphic $1 \cdot 1 / 0.9 \mathrm{~kb}$ fragments were detected by the exon 9 probe represented in fig 1. The maternal allele specific hypomethylation site was therefore localised at exon 9 of the IGF-II gene.

ALLELE METHYLATION OF THE INSULIN AND CALCITONIN GENES IN CONTROL LEUCOCYTES The same methodology was used to investigate methylation of two other genes localised on the short arm of chromosome 11, insulin (11p15.5) and calcitonin (11p15.1). For the insulin gene, both alleles were partially demethylated, indicating an absence of allele specific demethyla-
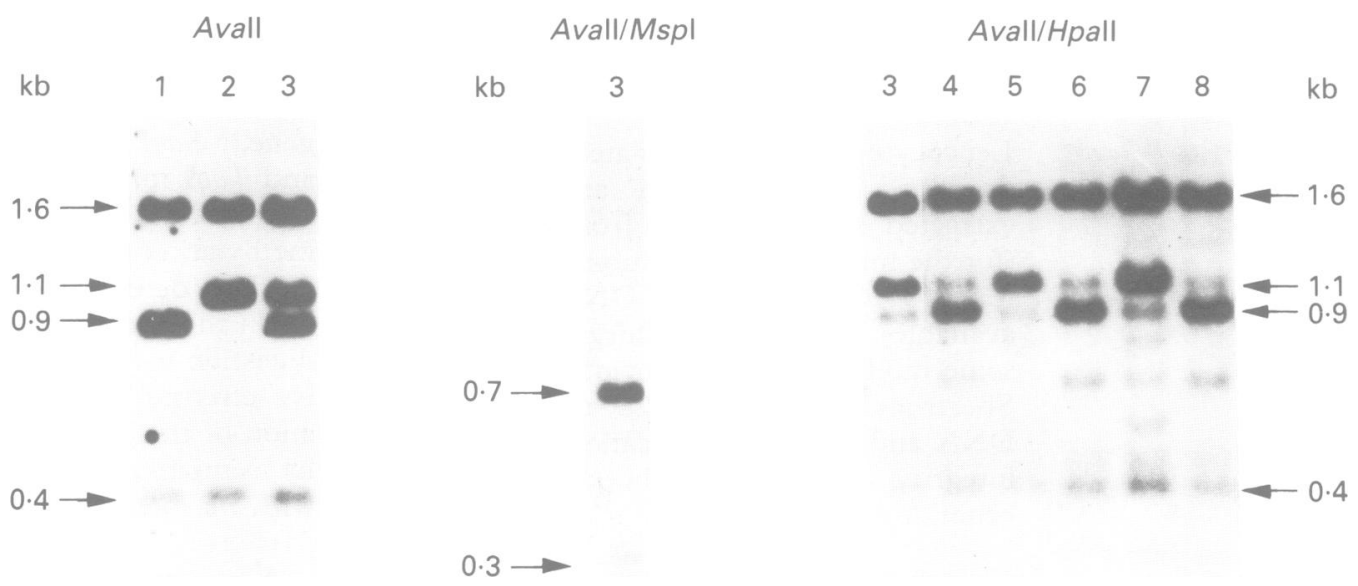

Figure 2 Southern blot analysis of control leucocyte DNA digested with AvaII, AvaII/MspI, or AvaII/HpaII, using IGF-II cDNA as probe. (1) Homozygote for the $0.9 \mathrm{~kb}$ fragment. (2) Homozygote for the $1 \cdot 1 \mathrm{~kb}$ fragment. $(3,4,5,6,7,8)$ Unrelated heterozygotes for the $0 \cdot 9 / 1 \cdot 1 \mathrm{~kb}$ fragments.

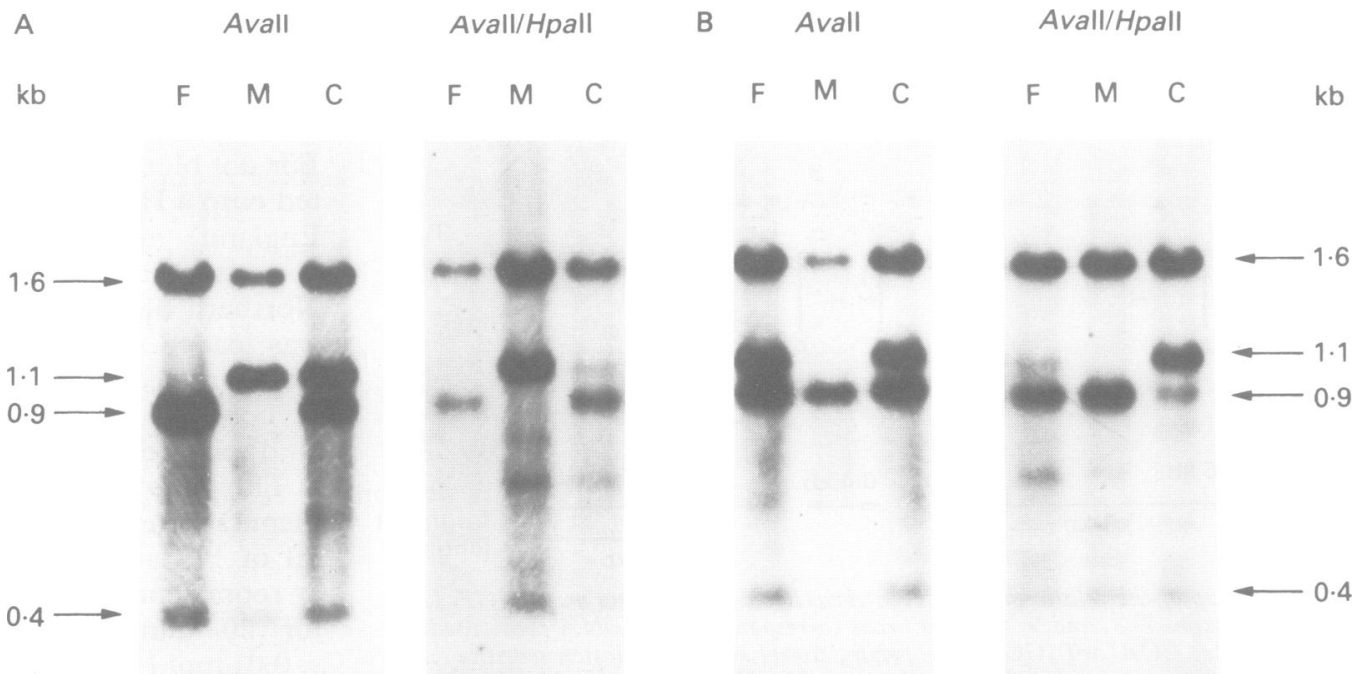

Figure 3 Family study: Southern blot analysis of leucocyte DNA digested with AvaII and AvaII/HpaII, using IGF-II cDNA as probe. Two control families ( $A$ and $B$ ) were examined. $F$, father; $M$, mother; $C$, child. 


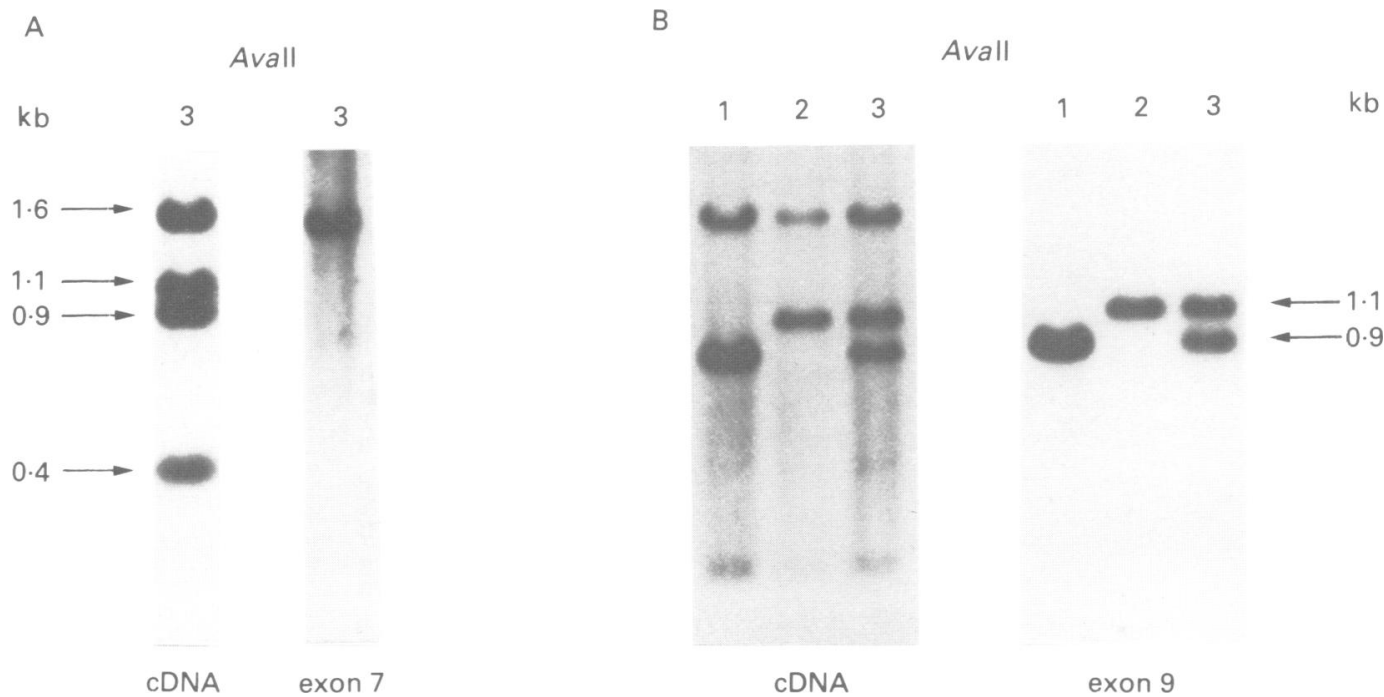

Figure 4 Southern blot analysis of control leucocyte DNA digested with AvaII, using the IGF-II cDNA probe (exons $7,8,9$ ) and exon $7(A)$ or exon 9 (B) specific probes. (1) Homozygote for the $0.9 \mathrm{~kb}$ fragment, (2) homozygote for the $1 \cdot 1 \mathrm{~kb}$ fragment, (3) heterozygote for the $0 \cdot 9 / 1 \cdot 1 \mathrm{~kb}$ fragments.

tion, at least in the region of the polymorphic fragments (data not shown). In the case of the calcitonin gene, double digestion with $T a q \mathrm{I} /$ HpaII yielded two polymorphic fragments which were shorter than those obtained after TaqI alone, indicating total demethylation of both alleles, without any allele specificity for the polymorphic fragments studied (fig 5).

\section{ANALYSIS OF THE INSULIN/IGF-II LOCUS IN PATIENTS WITH BECKWITH-WIEDEMANN SYNDROME}

The genome of children with Beckwith-Wiedemann syndrome was analysed in order to

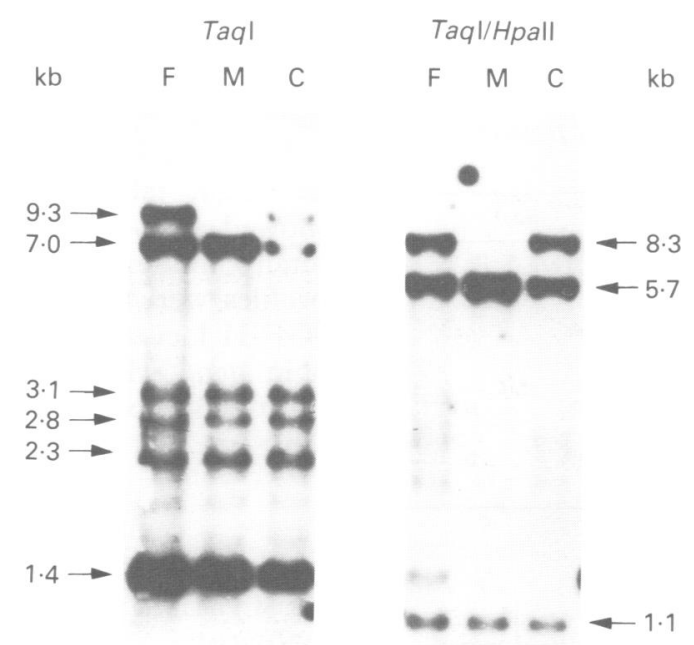

Figure 5 Southern blot analysis of control leucocyte $D N A$ from a control family, using the calcitonin cDNA probe with TaqI or TaqI/HpaII. F, father; $M$, mother; C, child. determine whether abnormalities were implicated at the insulin/IGF-II locus. Leucocyte DNA was analysed in the 29 patients listed in table 1, 20 of whom were diagnosed as having Beckwith-Wiedemann syndrome (P1$\mathrm{P} 19$, including $\mathrm{P} 3 \mathrm{C} 1$ and $\mathrm{P} 3 \mathrm{C} 2$ ). In addition, samples of tissue DNA (following partial glossectomy or tumorectomy) were examined when they were available. AvaII, SacI, and TaqI were used to analyse the restriction fragment length polymorphisms (RFLP) at the insulin/IGF-II locus as mentioned above. For the calcitonin gene, a control gene distal to the insulin/IGF-II locus, TaqI was used. Where possible, the study was extended to family analyses.

Among the 29 patients examined, seven were homozygous for the insulin/IGF-II locus and therefore non-informative (P4, P6, P10, P20, P22, P26, and P27) (data not shown). Out of the 22 informative cases, five exhibited profiles with abnormalities (P1, P3C1, P3C2, $\mathrm{P} 9$, and P24, as described in detail below and in table 2) and the remaining 17 had normal heterozygote profiles for either the IGF-II gene (P2, P11, P13, P15, P16C1, P16C2, P18, $\mathrm{P} 19, \mathrm{P} 21, \mathrm{P} 23)$ or the insulin gene $(\mathrm{P} 5, \mathrm{P} 7, \mathrm{P} 8$, P12, P14, P16C1, P17, P18, P19, P23). Allele frequencies of $A v a I I$ and SacI RFLPs at the IGF-II gene were the same as those of the control population, both in the group of 15 unrelated children with Beckwith-Wiedemann syndrome and in the group of 19 cases considered to have complete or incomplete Beckwith-Wiedemann syndrome (table 3). Furthermore, if the four contiguous loci, AvaII, SacI for the IGF-II gene, and TaqI, SacI for the insulin gene, were taken together, the numbers of homozygotes and heterozygotes were no different from the controls (table 4).

In four out of the 16 cases with BeckwithWiedemann syndrome (P1, P3C1, P3C2, and P9) abnormal heterozygote profiles were detected for the insulin/IGF-II locus. These are represented in table 2 and shown in fig 6 where disproportionate allele intensities were detected, suggesting uniparental disomy for 
Table 2 Genotypes of some patients with either Beckwith-Wiedemann syndrome or isolated tumours. Southern blot analysis of the IGF-II gene (AvaII and SacI), insulin gene (SacI and TaqI), and calcitonin gene (TaqI).

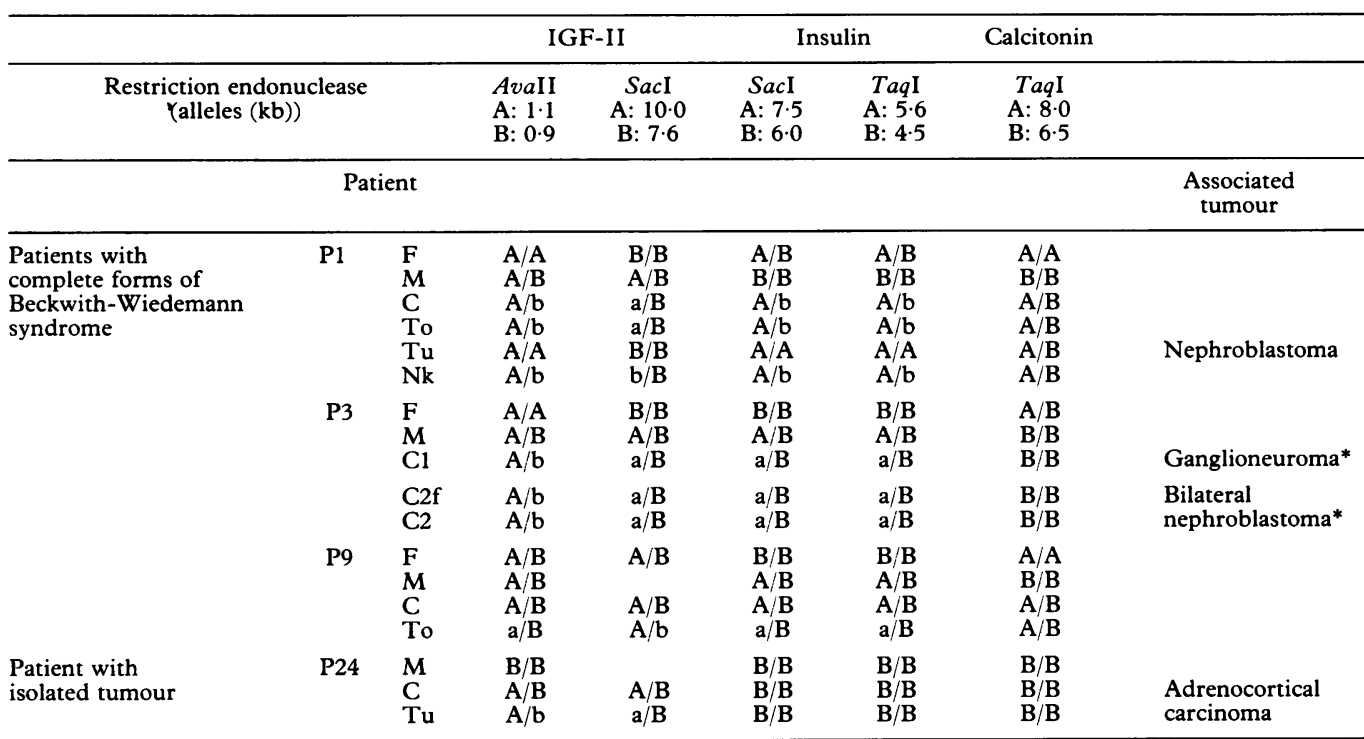

$\mathrm{F}=$ father. $\mathrm{M}=$ mother. $\mathrm{C}=$ affected child. $\mathrm{To}=$ tongue tissue after partial glossectomy. $\mathrm{Tu}=$ tumour after tumorectomy $\mathrm{Nk}=$ normal kidney.

$\mathrm{C} 1$ and $\mathrm{C} 2$ were two affected children from the same family (see table 1), C2f being a fetal sample from the child $\mathrm{C} 2$.

Alleles are represented as $A$ and $B$.

$\mathrm{A} / \mathrm{b}$ or $\mathrm{a} / \mathrm{B}$ : disproportionate profile, the less abundant allele being printed in lower case.

*Tissue not available.

the insulin/IGF-II locus. In the nephroblastoma of $\mathrm{Pl}$, the maternal allele $(0.9 \mathrm{~kb})$ was totally missing (fig 6). Allele loss was also detectable in leucocyte DNA in P1, but a heterozygote profile with disproportionate intensities was visible in tongue (fig 6) and healthy kidney tissue (data not shown). In $\mathrm{P} 3 \mathrm{C} 1$ and her brother, $\mathrm{P} 3 \mathrm{C} 2$ (in fetal P3C2f and newborn P3C2 leucocyte DNA), heterozygote profiles were detectable, but allele intensities were also disproportionate (fig 6). P9 had a normal heterozygote leucocyte DNA profile, but a disproportionate profile for

Table 3 Allele frequencies of AvaII and SacI polymorphisms at the IGF-II locus (11p15.5) in Beckwith-Wiedemann syndrome patients.

\begin{tabular}{lcccc}
\hline & \multicolumn{2}{c}{ AvaII } & \multicolumn{2}{c}{ SacI } \\
\cline { 2 - 5 } Alleles & A: $1 \cdot 1 \mathrm{~kb}$ & B: $0.9 \mathrm{~kb}$ & A: $10 \cdot 0 \mathrm{~kb}$ & B: $7 \cdot 6 \mathrm{~kb}$ \\
\hline $\begin{array}{l}\text { Complete forms of } \\
\text { Beckwith-Wiedemann } \\
(\mathrm{n}=15)\end{array}$ & $70.0 \%$ & $30.0 \%$ & $36 \cdot 7 \%$ & $63.3 \%$ \\
$\begin{array}{l}\text { Complete and incomplete forms of } \\
\text { Beckwith-Wiedemann } \\
(\mathrm{n}=19)\end{array}$ & $68.4 \%$ & $31.6 \%$ & $36.8 \%$ & $63.2 \%$ \\
$\begin{array}{l}\text { Controls* } \\
(\mathrm{n}=37)\end{array}$ & $75 \cdot 0 \%$ & $25.0 \%$ & $35.0 \%$ & $65.0 \%$ \\
\hline
\end{tabular}

* Control population previously reported. ${ }^{15}$

Table 4 Homozygote and heterozygote frequencies of four RFLPs associated with Beckwith-Wiedemann syndrome, insulin (TaqI,SacI) and IGF-II

(SacI,AvaII) loci taken together.

\begin{tabular}{lcc}
\hline & $\begin{array}{c}\text { Frequency of } \\
\text { homozygosity }\end{array}$ & $\begin{array}{c}\text { Frequency of } \\
\text { heterozygosity }\end{array}$ \\
\hline $\begin{array}{l}\text { Complete forms of } \\
\text { Beckwith-Wiedemann } \\
(n=15)\end{array}$ & $20 \%$ & $80 \%$ \\
$\begin{array}{l}\text { Complete and incomplete } \\
\text { forms of }\end{array}$ & $16 \%$ & $84 \%$ \\
$\begin{array}{l}\text { Beckwith-Wiedemann } \\
(n=19)\end{array}$ & $18 \%$ & $82 \%$ \\
$\begin{array}{l}\text { Controls* } \\
(n=34)\end{array}$ & & \\
\hline
\end{tabular}

* Control population previously reported for the four contiguous loci (insulin/RsaI, insulin/HindIII, IGF-II/SacI, IGF-II/ AvaII). ${ }^{36}$ tongue tissue (fig 6). In addition, a $0.5 \mathrm{~kb}$ fragment was detected in tissue samples (tongue and tumour) after AvaII digestion, as previously detected in a number of other tissue samples. ${ }^{15}$ This was attributable to a specific AvaII site being methylation sensitive, depending on the tissue concerned (fig 1).

Among the four children with isolated tumours (P24-P27, table 1), tumoral DNA was available in only one case, P24, and an abnormal profile with disproportionate intensity was detected for the insulin/IGF-II locus (table 2). For this particular patient, the similar abnormal profile was detected in the adrenocortical carcinoma, but not in leucocyte, DNA (fig 6).

For these five patients $(\mathrm{P} 1, \mathrm{P} 3 \mathrm{C} 1, \mathrm{P} 3 \mathrm{C} 2, \mathrm{P} 9$, and P24, table 2), family analyses always showed a maternal origin of the partially or totally missing allele. The disproportionate profiles were located only at the insulin and IGF-II loci and did not extend to the calcitonin gene which, in the informative cases, exhibited a normal profile (patients P1 and P9, table 2).

IGF-II MRNA EXPRESSION IN TISSUE MATERIAL FROM PATIENTS WITH BECKWITH-WIEDEMANN SYNDROME

IGF-II mRNA expression was analysed in the tissues available to determine whether any disregulation was involved. On average, IGFII mRNA expression, measured by dot blot analysis in the tongue tissue of the eight patients having undergone partial glossectomy (P1, P6, P7, P8, P9, P10, P14, P20), was similar to that in normal adult liver used as a reference (fig $7 \mathrm{~A}$ and $\mathrm{B}$ ). In addition, there was no significant difference between the two cases of macroglossia where uniparental disomy had been detected (P1 and P9) and the others analysed. Moreover, the usual $6,4.8$, and 


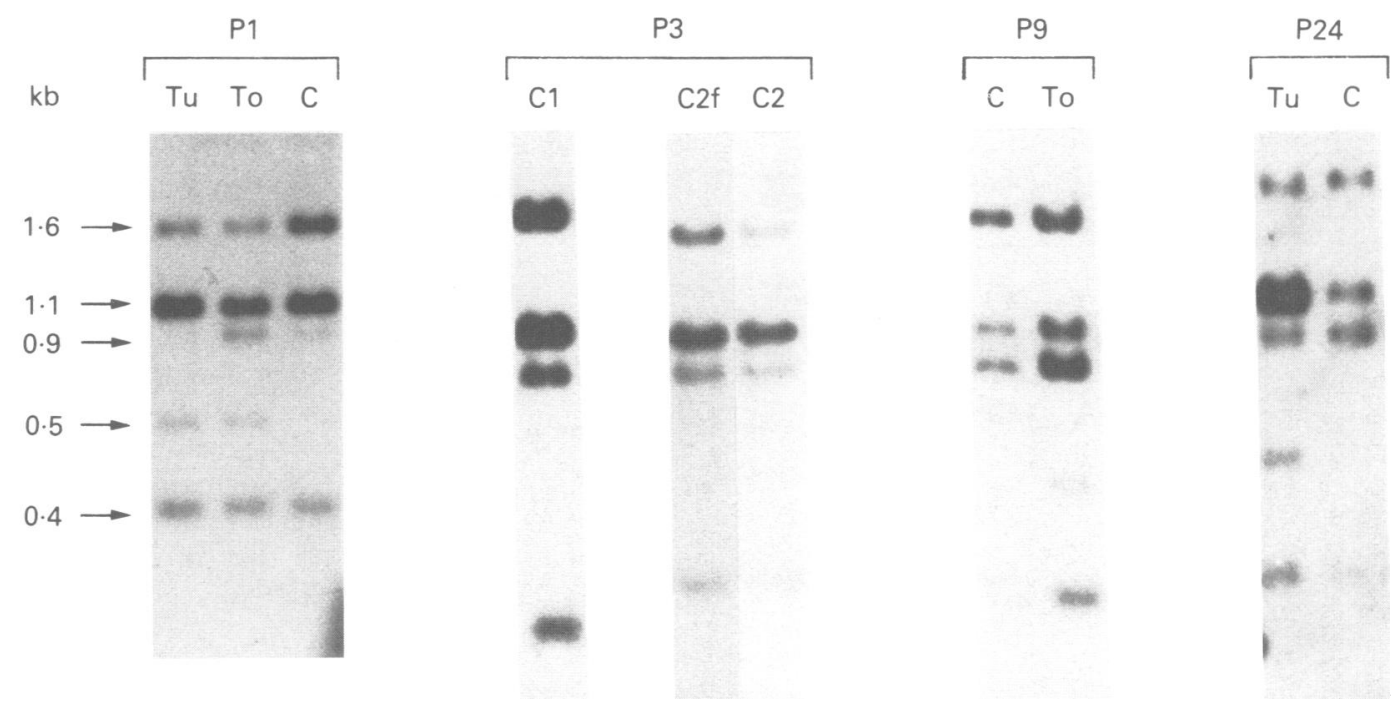

Figure 6 Southern blot analysis of genomic DNA digested with AvaII using IGF-II cDNA as probe for patients P1 (Tu: tumour, To: tongue, C: leucocytes), P3 (C1: leucocytes, C2f: fetal leucocytes, C2: newborn leucocytes), $P 9$ (C: leucocytes, To: tongue), and P24 (Tu: tumour, C: leucocytes).

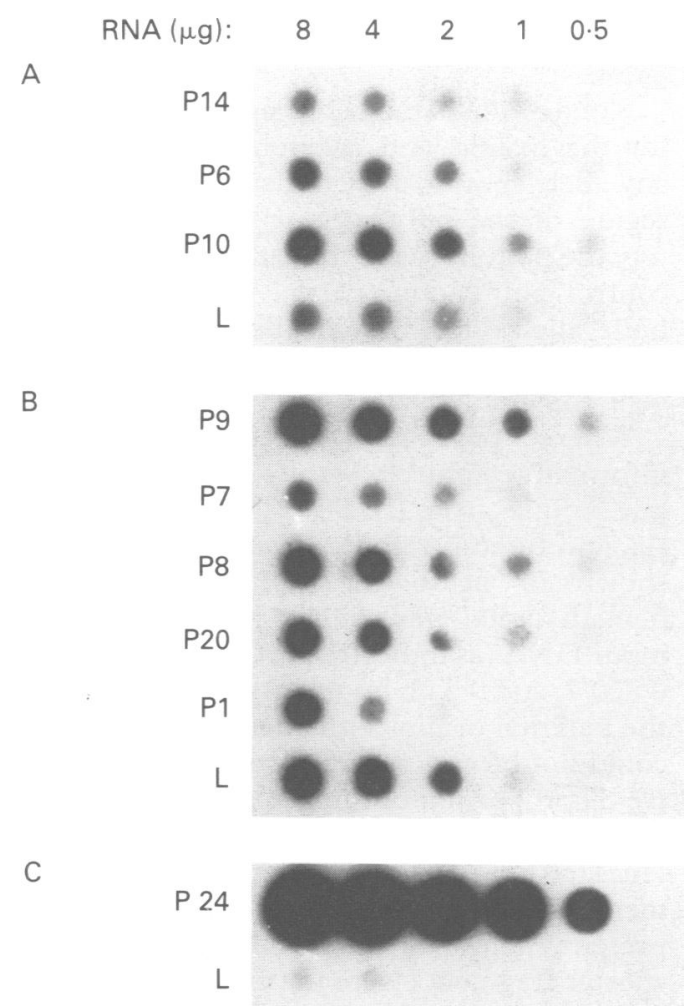

Figure 7 Dot blot analysis of IGF-II mRNA expression in tongue tissue (P1, P6-P10, P14, P20) from patients with macroglossia and in an adrenocortical carcinoma (P24). In each experiment normal adult liver $(L)$ was used as internal control. Exposure time: $A=$ six days, two intensifying screens; $B=$ four days, one intensifying screen; $C=16$ hours, two intensifying screens.

$2 \cdot 2 \mathrm{~kb}$ IGF-II mRNAs were detectable by Northern blot analysis (data not shown).

In the two samples of tumour tissue available, IGF-II mRNA expression could not be measured in the nephroblastoma of $\mathrm{P} 1$, who was undergoing chemotherapy at the time of surgery (data not shown), but in the adrenocortical carcinoma of P24, who was not under chemotherapy, extremely high levels of IGFII mRNA expression were found (fig 7C).

ALLELE SPECIFIC METHYLATION IN PATIENTS WITH BECKWITH-WIEDEMANN SYNDROME In order to determine whether allele specific methylation of leucocyte DNA may be linked to the Beckwith-Wiedemann syndrome, double digestion experiments were done and comparisons made with the control population. This type of analysis was possible only for subjects with heterozygous profiles for AvaII for the IGF-II gene. In 11 of these patients (P1, P3C1, P9, P11, P13, P15, P16C1, P18, P19, P21, P23), the patterns were similar to those for the control population, indicating that only one allele was hypomethylated (data not shown). In only one case (P2) did both alleles remain methylated (fig 8). In the five informative families of Beckwith-Wiedemann syndrome patients (P1, P2, P3, P13, and P19) specific hypomethylation was always found for the maternal allele (data not shown), as had 


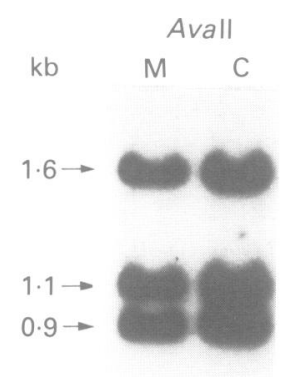

$0.4 \rightarrow$
Avall/Hpall

M C

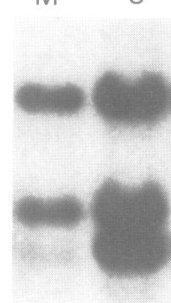

.

Figure 8 Southern blot analysis of patient P2 leucocyte DNA digested with AvaII or AvaII/HpaII, using $I G F-I I$ cDNA as probe. M, mother; $C$, affected child.

previously been observed for the control population.

None of the patients or families investigated for the insulin and calcitonin genes showed any allele specific demethylation at least in the region of the polymorphic fragments. Here, too, the patterns were the same as those for the control population: partial demethylation of both alleles for the insulin gene and total demethylation of both alleles for the calcitonin gene (data not shown).

Where possible, tissue samples from informative subjects were also analysed (tongue samples from P1, P9, P13 with macroglossia, and tumour samples from P1 and P24), as shown in fig 6. For Pl, IGF-II DNA demethylation was evident in tongue and tumour DNA (as indicated by the presence of the $0.8,0.7$, and $0.3 \mathrm{~kb}$ fragments, fig 9 ). However, the parental origin of the demethylated alleles could not be confirmed because of the extensive disproportion of the alleles (fig 6). For this patient, P1, it was possible to show with AvaII/HpaII digestion that the $0.9 \mathrm{~kb}$ fragment (which was maternal, table 2) was still present in tongue tissue, indicating that the shorter fragments were in part paternal (fig 9). In $\mathrm{P} 9$ and $\mathrm{P} 13$, both alleles $(1.1$ and $0.9 \mathrm{~kb})$ in tongue tissue were demethylated, whereas

leucocyte DNA still exhibited allele specific hypomethylation, only the $1.1 \mathrm{~kb}$ allele in $\mathrm{P9}$ or the $0.9 \mathrm{~kb}$ allele in P13 being demethylated (fig 9). For P24, without Beckwith-Wiedemann syndrome, both alleles of the adrenocortical carcinoma DNA were hypomethylated (fig 9). These preliminary findings for DNA methylation in the tissues of four informative subjects showed a difference between leucocyte and tissue DNA in patients with Beckwith-Wiedemann syndrome and the patient with an embryonic tumour, whereas allele specific demethylation in control tissues (placenta, peritumoral adult kidney tissue) was similar to that in control leucocyte DNA (data not shown).

\section{Discussion}

Allele specificity of human IGF-II gene methylation as related to parental origin has been investigated in both a control population and patients with Beckwith-Wiedemann syndrome where the IGF-II gene is thought to play a role. ${ }^{129}$ Differential parental imprinting of the IGF-II gene has been shown in the fetal mouse, ${ }^{18}$ but the molecular mechanism remains an enigma, despite transgenic studies suggesting that DNA methylation may be involved..$^{30}$

Our analyses of control leucocyte DNA methylation in the IGF-II gene have shown that allele specificity does indeed exist, since only one allele was demethylated in all cases. Family analyses showed that the hypomethylated allele was always maternal, which means that allele specific hypomethylation at the IGF-II gene is linked to parental origin. Moreover, allele specificity of methylation in the $11 \mathrm{p} 15$ region of the chromosome was limited to the IGF-II locus (11p15.5). The phenomenon was not observed either at the insulin gene $^{31}$ (this study) or at the calcitonin gene (this study), both alleles being demethylated simultaneously, either partially (insulin) or totally (calcitonin) in the area studied. Finally, we found the sites involved in this allele specific methylation of the IGF-II gene to be situated in the region of exon 9 .

In their homologous recombination studies of transgenic mice which were heterozygous
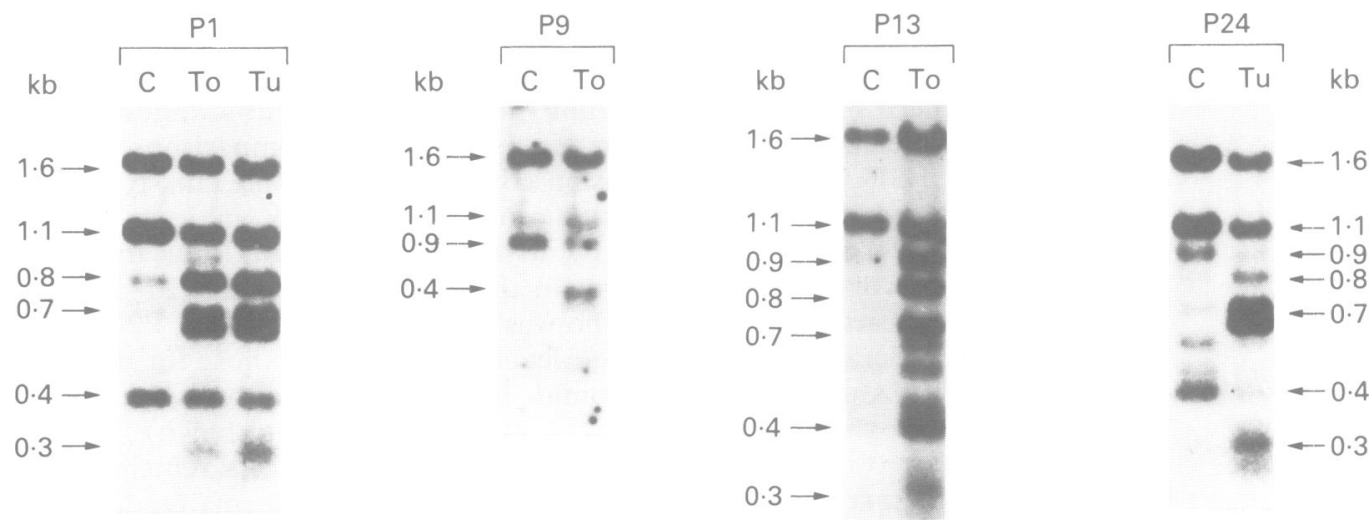

Figure 9 Southern blot analysis of genomic DNA digested with AvaII/HpaII, using IGF-II cDNA as probe, for patients P1, P9, P13, and P24. C=leucocytes from affected child, To=tongue, Tu=tumour (P1: neuroblastoma, P24: adrenocortical carcinoma). The AvaII patterns for the same patients are shown in fig 6 . 
for the mutant gene, DeChiara et al ${ }^{18}$ showed that only the paternal allele of the IGF-II gene was expressed embryonically, whereas the maternal allele remained silent. Our observations indicate that in man, allele specific methylation of the IGF-II gene varies with differential parental imprinting, the maternal allele being hypomethylated and the paternal allele methylated. The allele specific IGF-II gene methylation may be linked to mRNA expression, demethylation of a gene frequently being associated with expression. ${ }^{32}$ Nevertheless, our results suggest that the paternal allele is methylated at IGF-II exon 9 and is associated with expression of the paternal allele. This, as DeChiara et $a l^{18}$ proposed, may reflect negative imprinting, expression of a specific trans acting repressor inhibiting expression of the maternal, and thereby allowing expression of the paternal, allele.

We also examined the possibility of genetic abnormalities accounting for the BeckwithWiedemann syndrome. Southern blotting experiments using enzymes which show RFLPs showed that in these patients (table 1) no major chromosomal anomalies (like deletion or amplification) occurred in the $11 \mathrm{p} 15$ region.

Loss of heterozygosity has been described in tumours where the short arm of chromosome $11(11 \mathrm{p} 13-11 \mathrm{p} 15)$ is involved, ${ }^{33}$ and particularly in Wilms' tumour. ${ }^{34}{ }^{35}$ Henry et $a l^{36}$ reported increased leucocyte homozygosity in patients with the Beckwith-Wiedemann syndrome as compared to controls, but our findings do not support this, as we found the same frequency of homozygosity in the two groups ${ }^{37}$ (tables 3 and 4). This discrepancy may be explained by the fact that some apparent allele losses in fact reflect mosaics with grossly disproportionate alleles, which simulate homozygosity in some patients (as in patient 1, fig 6). Among the 'complete' Beckwith-Wiedemann syndrome patients examined in this study, three (P1, P3C1, P9) out of 15 unrelated subjects $(20 \%)$ (and four out of 16 when including P3C2) exhibited total allele loss or marked disproportion, and in all of them the maternal allele was lost (or very diminished) making duplication of the paternal allele possible. Uniparental disomy is probably only one of the mechanisms that accounts for BeckwithWiedemann syndrome. Among the cases of paternal isodisomy (P1, P3C1, P9), two out of three unrelated children developed tumours $(66 \%)$. A malignant tumour rate of $7.5 \%$ has been reported for Beckwith-Wiedemann syndrome. $^{5}$ The high rate found in cases of uniparental disomy (with a disproportionate pattern) could be important in genetic counselling as regards the risk of tumour in Beckwith-Wiedemann patients. Nevertheless, uniparental disomy has also been seen in nontumoral tissue (enlarged tongue and leucocytes), which means that allele loss is not always accompanied by tumour formation in these particular tissues ${ }^{37}$ (this study). For two patients (P1 and P9), we were able to show that the mosaic disomy was limited to the distal $11 \mathrm{p}$ region (calcitonin not included). The presence of disproportionate allele intensities was probably the result of mosaicism for two types of cell, the normal (with normal heterozygote DNA) and the paternal isodisomy cells. This therefore concerns a post-zygotic event, with mitotic recombination, and indicates a low recurrence risk for a second child in a Beckwith-Wiedemann syndrome family. It also throws some light on the genetic mechanism involved. The recurrence of somatic mosaicism in the two sibs (P3C1 and P3C2) was highly improbable and suggests that an abnormal paternal $11 \mathrm{p} 15$ chromosome was transmitted.

As in the control population, allele specificity of IGF-II gene methylation was observed in leucocyte DNA of patients with BeckwithWiedemann syndrome. Hypomethylation of the maternal allele and methylation of the paternal allele were seen in both groups. In only one case, P2, were both constitutive leucocyte alleles abnormally methylated, whereas insulin and calcitonin gene methylation resembled that of normal controls. Here, both IGFII alleles could have been submitted to similar paternal imprinting, suggesting a mechanism different from loss of the maternal allele with paternal duplication.

Tissue (tongue or tumour) DNA methylation in patients with Beckwith-Wiedemann syndrome proved to be different from leucocyte DNA methylation. In these patients the paternal allele of the IGF-II gene was demethylated, whether or not loss of heterozygosity had occurred. The abnormal paternal allele methylation may therefore be specific to children with Beckwith-Wiedemann syndrome and embryonic tumours.

Our study indicates that there is a link at the level of the adult human IGF-II gene between methylation and differential parental imprinting. It may be that methylation is involved in uniparental disomy and hence in the pathogenesis of Beckwith-Wiedemann syndrome. Finally, the exon 9 region of the IGF-II gene, where parental allele specific methylation is found, may play a role in regulating IGF-II gene expression.

This work was supported by the Institut National de la Santé et de la Recherche Médicale (INSERM), the Contrat de Recherche Clinique de l'Assistance Publique (CRCAP 89-57, CRCAP 923107), the Fondation pour la Recherche Médicale-92, and the Université Paris VI. H Schneid is a recipient of a fellowship of the Fondation pour la Recherche Médicale. We are grateful to Dr M Binoux for his support and to Dr M Mannens for helpful discussion. We thank Drs J J Baudon, A Bensman, P Brun, I Grapin, M Gruner, G Lasfargues, M Maes, A Masson, and R Rappaport for donating samples for analysis.

1 Koufos A, Grundy P, Morgan K, et al. Familial Wiedemann-Beckwith syndrome and a second Wilms' tumo locus both map to 11 p15.5. Am 7 Hum Genet 1989;44:711-9.

2 Ping AJ, Reeve AE, Law DJ, Young MR, Boehnke $M$, Feinberg AP. Genetic linkage of Beckwith-Wiedeman syndrome to $11 \mathrm{p} 15$. Am 7 Hum Genet 1989;44:720-3.

3 Tricoli JV, Rall LB, Scott J, Bell GI, Shows TB. Localization of insulin-like growth Bell GI, Shows TB. Localizasomes 11 and 12. Nature 1984;310:784-6.

4 Sotelo-Avila C, Gonzalez-Crussi F, Fowler JW. Complete and incomplete forms of Beckwith-Wiedemann syn- 
drome: their oncogenic potential. $\mathcal{F}$ Pediatr 1980;96:4750.

5 Pettenati MJ, Haines JL, Higgins RR, Wappner RS, Palmer CG, Weaver DD. Wiedemann-Beckwith syndrome: presentation of clinical and cytogenetic data on 22 new cases and review of the literature. Hum Genet 1986;74:143-54.

6 Blatt J, White C, Dienes S, Friedman H, Foley TJR. Production of an insulin-like growth factor by osteosa

7 Reeve AE, Eccles MR, Wilkins RJ, Bell GI, Millow LJ. Expression of insulin-like growth factor-II transcripts in Expression of insulin-like growth factor-I
Wilms' tumour. Nature 1985;317:258-60.

8 Scott J, Cowell J, Robertson ME, et al. Insulin-like growth factor-II gene expression in Wilms' tumour and embryonic tissues. Nature 1985;317:260-2.

9 Haselbacher GK, Irminger JC, Zapf J, Ziegler WH, Humbel RE. Insulin-like growth factor II in human adrenal pheochromocytomas and Wilms' tumors: expression at the mRNA and protein level. Proc Natl Acad Sci USA 1987;84:1104-6.

10 Tricoli JV, Rall LB, Karakousis CP, et al. Enhanced levels of insulin-like growth factor messenger RNA in human
colon carcinomas and liposarcomas. Cancer Res 1986;46:6169-73.

11 Huff KK, Kaufman D, Gabbay KH, Spencer EM, Lippman ME, Dickson RB. Secretion of an insulin-like growth factor-I-related protein by human breast cancer growth factor-I-related protein

12 Yee D, Cullen KJ, Paik S, et al. Insulin-like growth factor II mRNA expression in human breast cancer. Cancer Res 1988;48:6691-6.

13 Gray A, Tam AW, Dull TJ, et al. Tissue-specific and developmentally regulated transcription of the insulinlike growth factor 2 gene. DNA 1987;6:283-95.

14 Gloudemans T, Prinsen I, Van Unnik JA, Lips CJ, Den Otter W, Sussenbach JS. Insulin-like growth factor gene expression in human smooth muscle tumors. Cancer Res 1990;50:6689-95.

15 Schneid H, Seurin D, Noguiez P, Le Bouc Y. Abnormalities of insulin-like growth factor (IGF-I and IGF-II) genes in human tumor tissue. Growth Regulation 1992;2:45-54.

16 Daughaday WH, Rotwein P. Insulin-like growth factors I and II. Peptide, messenger ribonucleic acid and gene and II. Peptide, messenger ribonucleic acid and gene
structures, serum, and tissue concentrations. Endocrinol structures, serum, and
$R e v 1989 ; 10: 68-91$.

17 DeChiara TM, Efstratiadis A, Robertson EJ. A growthdeficiency phenotype in heterozygous mice carrying an insulin-like growth factor II gene disrupted by targeting. Nature 1990;345:78-80.

18 DeChiara TM, Robertson EJ, Efstratiadis A. Parental imprinting of the mouse insulin-like growth factor II gene. Cell 1991;64:849-59.

19 Reik W, Collick A, Norris ML, Barton SC, Surani MA. Genomic imprinting determines methylation of parental alleles in transgenic mice. Nature 1987;328:248-51.

20 Sapienza C, Peterson AC, Rossant J, Balling R. Degree of methylation of transgenes is dependent on gamete of origin. Nature 1987;328:251-4.

21 Schneid H, Le Bouc Y, Seurin D, et al. Insulin-like growth factor-I gene analysis in subjects with constitutionally variant stature. Pediatr Res 1990;27:488-91.

22 Chirgwin JM, Przybyla AE, MacDonald RJ, Rutter WJ. Isolation of biologically active ribonucleic acid from sources enriched in ribonuclease. Biochemistry 1979;18:5294-9.

23 Le Bouc Y, Noguiez P, Sondermeijer P, Dreyer D, Girard $\mathrm{F}$, Binoux M. A new $5^{\prime}$-non-coding region for human placental insulin-like growth factor II mRNA expression. placental insulin-like growth

24 Holthuizen PE, LeRoith D, Lund PK, et al. In: Spencer $\mathrm{EM}$, ed. Revised nomenclature for the insulin-like growth $\mathrm{EM}$, ed. Revised nomenclature for the insulin-like growth
factor genes and transcripts. Modern concepts of insulin-like factor genes and transcripts. Modern concepts of insulin-like
growth factors. New York: Elsevier Science Publishing growth factors.
Co, 1991:733-6.

25 Bell GI, Pictet RL, Rutter WJ, Cordell B, Tischer E, Goodman HM. Sequence of the human insulin gene. Nature 1980;284:26-32.

26 Le Moullec JM, Jullienne A, Chenais J, et al. The complete sequence of human preprocalcitonin. FEBS Lett 1984;167:93-7.

27 Bell GI, Horita S, Karam JH. A polymorphic locus near the human insulin gene is associated with insulin-dependent diabetes mellitus. Diabetes 1984;33:176-83.

28 Hoppener JW, Steenbergh PH, Zandberg J, et al. Localization of the polymorphic human calcitonin gene on chromosome 11. Hum Genet 1984;66:309-12.

29 Little M, Van Heyningen V, Hastie N. Dads and disomy and disease. Nature 1991;351:609-10.

30 Surani MA, Reik W, Allen ND. Transgenes as molecular probes for genomic imprinting. Trends Genet 1988;4:5962.

31 Ghazi H, Magewu AN, Gonzales F, Jones PA. Changes in the allelic methylation patterns of $\mathrm{c}-\mathrm{H}$-ras-1, insulin and retinoblastoma genes in human development. Development 1990;suppl:115-23.

32 Cedar H. DNA methylation and gene activity. Cell 1988;53:3-4.

33 Ponder B. Cancer. Gene losses in human tumours. Nature 1988;335:400-2.

34 Mannens M, Slater RM, Heyting C, et al. Molecular nature of genetic changes resulting in loss of heterozygosity of chromosome 11 in Wilms' tumours. Hum Genet 1988;81:41-8.

35 Mannens M, Devilee P, Bliek J, et al. Loss of heterozygosity in Wilms' tumors, studied for six putative tumor suppressor regions, is limited to chromosome 11. Cancer Res 1990;50:3279-83.

36 Henry I, Bonaiti-Pellie C, Chehensse V, et al. Uniparental paternal disomy in a genetic cancer-predisposing syndrome. Nature 1991;351:665-7.

37 Schneid H, Vasquez MP, Seurin D, Le Bouc Y. Loss of heterozygosity in non-tumoral tissue in two children with Beckwith-Wiedemann syndrome. Growth Regulation 1991;1:168-70. 